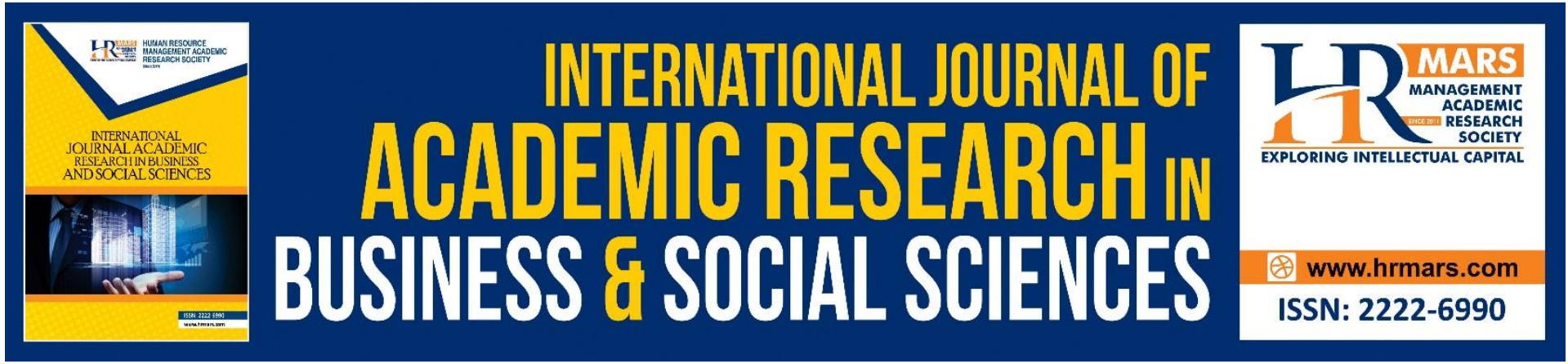

\title{
Code-Switching Practice in English Language Classrooms among Malaysian Teachers
}

Dora Anak Raki and Nur Ainil Sulaima

To Link this Article: http://dx.doi.org/10.6007/IJARBSS/v11-i8/10555

DOI:10.6007/IJARBSS/v11-i8/10555

Received: 08 June 2021, Revised: 13 July 2021, Accepted: 03 August 2021

Published Online: 17 August 2021

In-Text Citation: (Raki \& Sulaima, 2021)

To Cite this Article: Raki, D. A., \& Sulaima, N. A. (2021). Code-Switching Practice in English Language Classrooms among Malaysian Teachers. International Journal of Academic Research in Business and Social Sciences, 11(8), 534-549.

Copyright: (c) 2021 The Author(s)

Published by Human Resource Management Academic Research Society (www.hrmars.com)

This article is published under the Creative Commons Attribution (CC BY 4.0) license. Anyone may reproduce, distribute, translate and create derivative works of this article (for both commercial and non-commercial purposes), subject to full attribution to the original publication and authors. The full terms of this license may be seen at: http://creativecommons.org/licences/by/4.0/legalcode

Vol. 11, No. 8, 2021, Pg. 534 - 549

http://hrmars.com/index.php/pages/detail/IJARBSS

JOURNAL HOMEPAGE

Full Terms \& Conditions of access and use can be found at http://hrmars.com/index.php/pages/detail/publication-ethics 


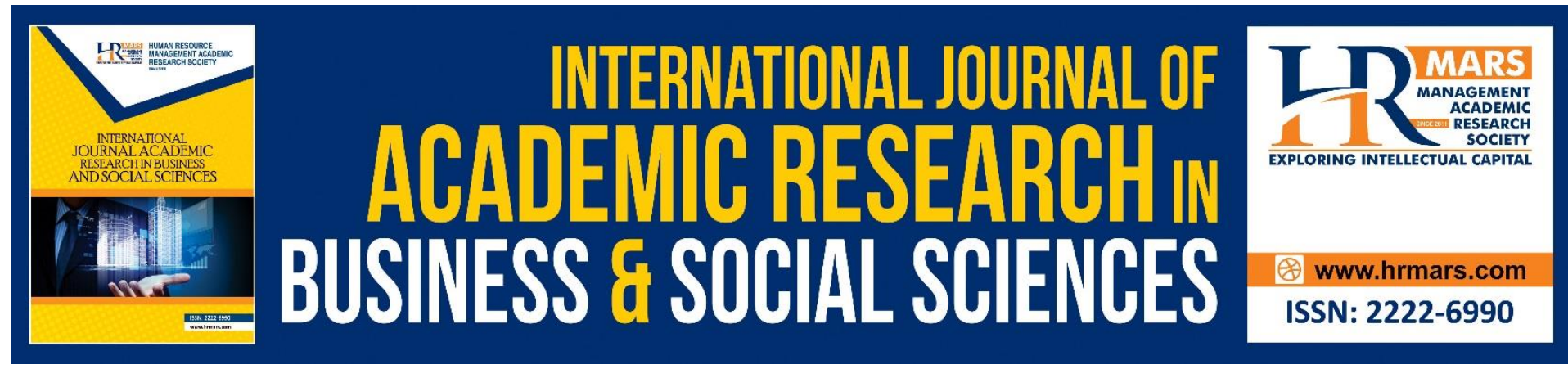

\title{
Code-Switching Practice in English Language Classrooms among Malaysian Teachers
}

\author{
Dora Anak Raki and Nur Ainil Sulaiman \\ Faculty of Education, Universiti Kebangsaan Malaysia \\ Email: dorahope85@gmail.com
}

\begin{abstract}
In Malaysian education system, English is taught as a second language, but the reality may not be true for some learners. Consequently, code-switching is inevitable among bilinguals teachers as they are used to maintain communication where L1 and L2 are used for different purposes in ESL classroom. Only a few studies were done to discover the code-switching functions among in-service teachers in English language classrooms which lead to aims of the present study. Code-switching is beneficial in ESL classrooms and teachers should know when and how it is best used. This is a survey study that utilized questionnaires as an instrument to collect data. A total of forty-two in-service English teachers currently studying at Universiti Kebangsaan Malaysia were chosen as the participants. The participants are chosen through purposive sampling because they are all English teachers teaching in ESL classrooms. The results suggested that the teachers have mixed perceptions on the use of code-switching. Furthermore, they advocated for judicious use of code-switching besides using it to help low proficiency learners. This perception further influences their use of code-switching where it was revealed that the teachers use code-switching mostly to help learners understand lesson content. Future research should focus on determining the correlation between teaching experience and the use of code-switching.
\end{abstract}

Keywords: Code-Switching, Esl Classrooms, Bilinguals, Teachers' Perceptions, Functions

\section{Introduction}

Malaysia has an estimated population of 31 million which consists of $50 \%$ Malays, $25 \%$ Chinese, $10 \%$ Indian and $15 \%$ indigenous people who are mainly from Sabah dan Sarawak (David et al., 2017). Therefore, the majority of Malaysians are bilinguals if not multilinguals as they are of multicultural backgrounds. Malay language has been the national and official language of Malaysia since its independence; thus, its functions and roles are not to be questioned. It is also the first language of many Malaysians, especially the Malays. Meanwhile, people of other races use different L1 according to their ethnicity and family background. In Malaysian education system, English is taught as a second language, but the reality may not be true for some learners. For instance, a learner from a Bidayuh ethnicity learns his/her own mother tongue at home before learning Malay language from the community. It shows that English is not his/her second language. Therefore, it can further pose more obstacles in the language learning as the different learners have different exposure time to English (Iber, 
2016). It is a daunting task to acquire a new language which is morphologically and syntactically different from the learner's L1. Furthermore, the mastery of a new language relies mostly on the exposure and practice they have on the language.

In the case of second language acquisition, it is almost impossible to learn L2 without referring to L1 as prior knowledge and using L1 as guidance or point forward. As opined by Manara (2007), the learners' mother tongue acts as a resource for them to get knowledge before they take on the new language. She further elaborated on using L1 as a learning strategy to help minimize the emotional obstacles in L2 acquisition and calm learners' anxiety so that they would be able to progress well in their L2 learning. Hence, code-switching is inevitable among bilinguals as they are used to maintain communication where L1 and L2 are used for different purposes. It has become a linguistic phenomenon among bilinguals and multilinguals although no similar understanding has been met by linguists, educators, and policy makers (Selamat, 2014). It is also dominant and has developed to be a part of a distinctive language style in both official and casual settings by professionals, adults and even children (DeAlwis, 2020). Code-switching is expected among language learners as a way for them to express themselves inside or outside the classroom, especially when they are not very proficient in the language. Due to this, teachers may opt to practice code-switching in language classrooms to ensure the content is understood. Nonetheless, teachers who employ code-switching in their ESL classrooms must create certain ground rules to make sure a judicious use of L1 (Makulloluwa, 2013). The switching might be done either naturally and subconsciously (Wardhaugh \& Fuller, 2014) or with a purpose in mind but either way, there are many factors that cause code switching to occur.

\section{Research Problem}

In recent years, more scholars and teachers began to encourage a more bilingual approach to teaching where L1 is used sensibly in L2 classrooms. Code-switching has become one of the language learning strategies utilized by teachers and learners to achieve proficiency in the target language. As Malaysia practices bilingual education where Malay and English language are taught as compulsory subjects since pre-school, the code-switching phenomenon started then and all the way to adulthood (Cheng, 2003). Low proficiency learners feel comfortable when teachers code-switch because their vocabulary repository is still inadequate. Hence, they showed positive attitudes in the classroom which helped them to enjoy and understand the lesson (Ahmad \& Jusoff, 2009). Therefore, code-switching in ESL classrooms has become a common practice or interaction between teachers and learners.

Code-switching is a technique used by teachers who share the same first language as the learners, especially the low proficiency learners (Selamat, 2014). The learners' learning process is facilitated by teachers' code-switching, and this leads to efficient delivery of classroom lessons. Still, the use of code-switching is viewed differently by different stakeholders. English teachers may be aware of the use of code-switching, but they may not entirely understand how to utilize it appropriately. On the other hand, they are also demanded to use English exclusively throughout the lessons although there is no certainty that they could avoid code-switching entirely. Thus, the teachers are still struggling and contemplating whether they should utilize code-switching during ESL lessons. Nevertheless, there must be a clear function and purpose to code-switching so that it is neither misuse nor overuse. Engku Haliza et al (2013) stated that teachers code-switch purposefully for various functions whereas Lee (2010) reiterated that the teachers should understand those functions. 
Only a few studies were done to discover the code-switching functions among in-service teachers in ESL classrooms. Code-switching is beneficial in ESL classrooms and teachers should know when and how it is best used. On the other hand, Selamat (2014) mentioned that teachers' negative perception towards code-switching resulted in monolingual teaching practices. Hence, there is a need to investigate the teachers' perceptions and practice of codeswitching to determine whether they are aware of its usage or acknowledge its advantages in ESL classrooms. Past studies conducted on teachers' perceptions of code-switching were mostly derived from teachers of the same background, i.e primary school, secondary schools, or tertiary education teachers. Few studies looked at teachers from diverse backgrounds. Hence, in this study, the teachers came from different school backgrounds, location, and teaching experiences. The researchers hope the results gained from this study can further help teachers and policy makers in mapping purposeful and judicious code-switching practice within ESL classrooms.

\section{Research Objectives}

1. To investigate in-service teachers' perceptions on the use of code-switching in ESL classrooms.

2. To examine in-service teachers' code-switching practice in ESL classrooms.

\section{Research Questions}

1. What are in-service teachers' perceptions on the use of code-switching in ESL classrooms?

2. How do in-service teachers practice code-switching in ESL classrooms?

\section{Literature Review \\ Code-switching Definitions}

Many researchers had suggested several definitions of code-switching. Gumperz (1982) stated that code switching is "the juxtaposition within the same speech exchange of passages of speech belonging to two different language/grammatical systems or subsystems" (p.59) whereas Milroy \& Muysken (1995) demarcated code-switching as "the alternating use of several languages by bilingual speakers" (p.7). They further posited that code-switching does not imply that the speakers are not proficient in the language but rather shows their intricate bilingual skills. In more recent studies, Khusmah \& Su-Hie (2016) proposed that codeswitching is "an inherent feature of language use in speech communities" (p.31) while Benu (2018) explained that code-switching happens when a language speaker shifts to another language midway into their speech or in the centre of a sentence.

\section{Teachers' Perceptions}

According to a study conducted by DeAlwis (2020), it was clear that the teachers who have negative perceptions toward code-switching use less of it in their classroom. Although in some instances, they agreed that code-switching is unavoidable, they still believe that learners may face problems in the future when they encounter conversation with native English speakers as code-switching could thwart their fluency. While some teachers disapproved of the use of code-switching, they do give an exception to low proficient learners to save time when they explain difficult vocabulary. Other teachers argued that if codeswitching is permitted, bilingual proficiency may be inadequate. These teachers also believed that they would only resort to code-switching when other options have been tried. 
However uncertain the teachers may feel towards the benefits of classroom codeswitching, they must admit that code-switching is an accommodating approach in classroom contact, particularly when the goal is to effectively illuminate and transmit information to the learners. The teachers must believe that code-switching is unavoidable and see it as a useful practice when it is used as a language strategy to accommodate the learners' low proficiency and create a nurturing classroom climate (Makulloluwa, 2013). Tajgozari (2017) in his study on the factors contributing to the use of L1 in English classrooms found that most teachers portrayed their reluctance in using L1 even though the learners viewed code-switching positively. Teachers believed in using as much of the target language as possible since the classroom might be the only place where learners can listen and speak English.

\section{Code-switching Functions}

Code-switching has the ability to accelerate better comprehension among learners and to engage and conform the whole classroom to the lesson. In many studies conducted by different researchers, they mentioned that code-switching was sometimes done subconsciously. However, when teachers code-switch for a purpose, it brings a positive impact to the learners' language acquisition. Therefore, code-switching has been identified to serve some purposes that are beneficial for language learning. Among the many functions that are repeatedly stated are topic switch, affective functions, repetitive functions, and learners' conflict control (DeAlwis, 2020; Flyman-Mattsson \& Burenhult (1999); Sert, 2005). Other than that, it should be noted that $\mathrm{L} 1$ is used to give instructions to learners during classroom activities as a part of efficient class control. Learners will also gain positive attitudes towards the target language when the teachers are able to create a strong relationship with them.

On the surface, it is straightforward to assume that teachers code-switch only to make the learners understand the statements. Nonetheless, as Flyman-Mattsson \& Burenhult (1999) did a thorough investigation on code-switching in second language teaching of French, they indicated that code-switching is more than only translation. They laid out linguistic insecurity, topic switch, affective functions, socializing functions, and repetitive functions as the reasons for teachers' code-switching. These functions are further elaborated by Sert (2005) where topic switches are mostly done during grammar lessons meanwhile the affective function of code-switching is utilized so that teachers can develop close relations with the learners and establish a caring language classroom.

Although policy makers often reject the use of code-switching in the second language classrooms, the code-switching functions could not be denied in aiding linguistic comprehension. Ferguson (2003) divided the code-switching functions into three extensive categories:

1. Code-switching to understand the lesson content

2. Code-switching to manage discipline and classroom behaviour

3. Code-switching to build relationship and engage learners

\section{Studies on Code-switching}

Makulloluwa (2013) further supported the various roles of code-switching in classroom interaction by stating that $\mathrm{L} 1$ is used to explain difficult concepts, grammatical items, and complex vocabulary besides introducing new materials or discussing topics that are unique to the L1 culture. Moreover, teachers also use L1 to deal with the matters of administration especially among low proficiency learners. Teachers also seek oral feedback from the learners 
using their L1 so that they could clarify vague areas. As summarized by Paramesvaran \& Lim (2018) based on previous studies, clarification, repetition, and emphasizing important points to learners are among the reasons that lead to the use of code-switching in Malaysian ESL classrooms.

Code-switching is not merely teaching in the learners' L1 but it should be done the right way where difficult concepts can be clarified especially when learners are facing difficulty to comprehend a certain language input. Levine (2003); Sert (2005) both agreed that explaining using L1 is easier as it saves time and reduces confusion among learners thus, they would not perceive the language as difficult to learn. Chowdhury (2013) also consented that codeswitching saves time when teachers explain new and difficult concepts to the learners besides helping with their understanding. Moreover, learners could communicate effectively and comfortably with teachers through the use of code-switching in the classroom.

Other than that, teachers code-switch so that they can develop and maintain interpersonal relationships with the learners as it was proven that this relationship can bring positive impact to the learners' language learning. When teachers practice code-switching during ESL lessons, the learners view the teachers as being approachable and supportive. Lee (2010) also suggested that learners' personalities should be taken into consideration because extroverts may be more daring and active in the classroom as opposed to the introverts. Therefore, when teachers code-switch, these introverted learners could brave up and communicate without hesitation as their anxiety level decreased. Lee further supported that code-switching could encourage language learning because it makes learners feel more accepted and comfortable in the classroom especially during speaking activities.

\section{Negative Effects of Code-switching}

Although it was proved that code-switching can be a beneficial practice in ESL classrooms, there are also studies that discovered the pitfalls of excessive code-switching. In a study conducted by Paramesvaran \& Lim (2018), they discovered that when a teacher puts too much effort on code-switching, the teacher may overlook the needs to cater for good proficiency learners. Too many translations done in the classroom leads to boredom to these learners. Other than that, the learners also thought that repetition for easy and familiar words to them is unnecessary. This proves that teachers' code-switching should be done judiciously. The teachers must be reminded that English is the medium of instruction in the classroom so that they will strive to keep code-switching at a minimum but effective level. Chowdhury (2013) in her study on code-switching among tertiary students in Bangladesh concluded that teachers and learners alike should not abuse the practice of classroom code-switching and that code-switching should be viewed as an exception rather than as a norm.

\section{Methodology}

This is a survey study that utilized questionnaires as an instrument to collect data. A total of forty-two in-service English teachers currently studying at Universiti Kebangsaan Malaysia were chosen as the participants. The participants are chosen through purposive sampling because they are all English teachers teaching in ESL classrooms in primary or secondary schools and even in tertiary level institutions. 


\section{The Participants' Demographic Profile}

Table 1 shows the demographic profile of the teachers.

Table 1 : Teachers' Demographic Profile

\begin{tabular}{lcc}
\hline Demographic Profile & Frequency & Percentage (\%) \\
\hline Gender & & \\
\hline Male & 7 & 16.7 \\
Female & 35 & 83.3 \\
\hline Age (years old) & & \\
\hline $\mathbf{2 0}$ to $\mathbf{2 9}$ & 24 & 57.1 \\
$\mathbf{3 0}$ to $\mathbf{3 9}$ & 14 & 33.3 \\
$\mathbf{4 0}$ to $\mathbf{4 9}$ & 4 & 9.5 \\
\hline Teaching experience (years) & \\
\hline $\mathbf{0}$ to $\mathbf{4}$ & 18 & 42.9 \\
$\mathbf{5}$ to 10 & 17 & 40.5 \\
$\mathbf{1 1}$ to $\mathbf{1 5}$ & 4 & 9.5 \\
$\mathbf{1 6}$ to $\mathbf{2 0}$ & 3 & 7.1 \\
\hline Where they teach & & \\
\hline Primary School & 26 & 61.9 \\
Secondary School & 13 & 31.0 \\
Tertiary Institution & 3 & 7.1 \\
\hline Location of the School & & \\
\hline Urban & 13 & 31.0 \\
Suburban & 20 & 47.6 \\
Rural & 9 & 21.4
\end{tabular}

Based on the teachers' demographic profile, it can be determined that these teachers are from heterogenous backgrounds hence their perceptions and use of code-switching might differ.

\section{Instruments}

In this study, the questionnaire used was adapted from past studies by Selamat (2014), Chen \& Maarof (2017) and Ferguson (2003). The questionnaire was split into three sections as described by Table 2 below. 
Table 2 : Questionnaire's Details

\begin{tabular}{|l|l|l|}
\hline Sections & Items & Description \\
\hline Section I & $\begin{array}{l}\text { Demographic profile (gender, age, teaching } \\
\text { experience, where they teach, location of school) }\end{array}$ & $\begin{array}{l}\text { Teachers' } \\
\text { Information }\end{array}$ \\
\hline $\begin{array}{l}\text { Section } \\
\text { II }\end{array}$ & $\begin{array}{l}\text { The teachers' perceptions on code-switching in } \\
\text { the ESL classroom which consisted of 11 close- } \\
\text { ended questions with five-point Likert scale } \\
\text { between 1 (strongly disagree) to 5 (strongly } \\
\text { agree) }\end{array}$ & $\begin{array}{l}\text { Items 1-6, 9 \& 10 - Selamat } \\
\text { Items 7, 8 \& 11 - Chen \& } \\
\text { Maarof (2017) }\end{array}$ \\
\hline $\begin{array}{l}\text { Section } \\
\text { III }\end{array}$ & $\begin{array}{l}\text { 18 items of five-point where 1=Never; 2=Rarely; } \\
\text { 3= Sometimes; 4=Most of the time; 5=Always to } \\
\text { discover how teachers practice code-switching. }\end{array}$ & $\begin{array}{l}\text { These } \\
\text { functions arguson's based on } \\
\text { Fergen } \\
\text { extensive categories. }\end{array}$ \\
\hline
\end{tabular}

There is one open-ended question so that teachers may write their genuine thoughts about their own code-switching practice so that both close-ended and open-ended questionnaires could complement each other (Zohrabi, 2013). The questionnaire was distributed through Google forms link that was shared in Telegram and Whatsapp groups.

The data from the questionnaires were analyzed using descriptive statistics meanwhile the open-ended question in the questionnaire was analyzed thematically. 


\section{Findings and Discussions}

\section{Teachers' Perceptions on Code-switching Practice in ESL Classrooms \\ Positive Perceptions}

Table 3 displays positive teachers' perceptions on the use of code-switching in ESL classrooms where a higher percentage of teachers agree and strongly agree on all items in Table 3 except for Item 11.

Table 3 : Positive Perceptions

\begin{tabular}{|c|c|c|c|c|c|c|}
\hline Item & Teachers believe that: & $\begin{array}{l}\text { Strongly } \\
\text { Disagree }\end{array}$ & Disagree & $\begin{array}{l}\text { Neither } \\
\text { Agree nor } \\
\text { Disagree } \\
\end{array}$ & Agree & $\begin{array}{l}\text { Strongly } \\
\text { Agree }\end{array}$ \\
\hline 1 & $\begin{array}{l}\text { Code-switching will } \\
\text { facilitate the } \\
\text { language learning } \\
\text { process. }\end{array}$ & $\begin{array}{c}7.1 \% \\
(3)\end{array}$ & $\begin{array}{c}26.2 \% \\
(11)\end{array}$ & $11.9 \%(5)$ & $\begin{array}{c}38.1 \% \\
(16)\end{array}$ & $\begin{array}{c}16.7 \% \\
(7)\end{array}$ \\
\hline 3 & $\begin{array}{l}\text { Code-switching } \\
\text { should be included as } \\
\text { an integral part of the } \\
\text { ESL lesson. }\end{array}$ & $\begin{array}{c}4.8 \% \\
(2)\end{array}$ & $\begin{array}{c}40.5 \% \\
(17)\end{array}$ & $\begin{array}{c}7.1 \% \\
(3)\end{array}$ & $\begin{array}{c}38.1 \% \\
(16)\end{array}$ & $\begin{array}{c}9.5 \% \\
(4)\end{array}$ \\
\hline 7 & $\begin{array}{l}\text { Code-switching is } \\
\text { unavoidable. }\end{array}$ & $14.3 \%(6)$ & $14.3 \%(6)$ & $21.4 \%(9)$ & $35.7 \%(15)$ & $\begin{array}{c}14.3 \% \\
(6)\end{array}$ \\
\hline 8 & $\begin{array}{l}\text { Code-switching } \\
\text { should only be used } \\
\text { for weak learners. }\end{array}$ & $\begin{array}{c}9.5 \% \\
(4)\end{array}$ & $\begin{array}{c}28.6 \% \\
(12)\end{array}$ & $11.9 \%(5)$ & $\begin{array}{c}40.5 \% \\
(17)\end{array}$ & $\begin{array}{c}9.5 \% \\
(4)\end{array}$ \\
\hline 9 & $\begin{array}{l}\text { The use of other } \\
\text { languages in the ESL } \\
\text { classroom will result } \\
\text { in a decline in the } \\
\text { standard of English. }\end{array}$ & $\begin{array}{c}9.5 \% \\
(4)\end{array}$ & $19.0 \%(8)$ & $28.6 \%(12)$ & $\begin{array}{c}23.8 \% \\
(10)\end{array}$ & $\begin{array}{c}19.1 \% \\
(8)\end{array}$ \\
\hline 11 & $\begin{array}{l}\text { Code-switching } \\
\text { highlight teachers' } \\
\text { linguistic weaknesses }\end{array}$ & $11.9 \%(5)$ & $\begin{array}{c}40.5 \% \\
(17)\end{array}$ & $14.3 \%(6)$ & $\begin{array}{l}23.8 \% \\
(10)\end{array}$ & $\begin{array}{c}9.5 \% \\
(4)\end{array}$ \\
\hline
\end{tabular}

$54.8 \%$ teachers agreed that code-switching can facilitate the language learning process while $47.6 \%$ agreed that code-switching should be included in ESL lessons. The teachers also agreed that code-switching is unavoidable and useful for low proficiency learners. They do not think that the use of code-switching could decrease the standard of English. Meanwhile, 52.4\% of the teachers disagreed that code-switching highlights the teachers' linguistic awareness which was also posited by Milroy \& Muysken (1995). These findings proved that teachers use code-switching to help learners learn language easily. 


\section{Negative Perceptions}

Table 4 displays negative teachers' perceptions on the use of code-switching in ESL classrooms where a higher percentage of teachers agreed to the negative effects of codeswitching.

Table 4: Negative Perceptions

\begin{tabular}{|c|c|c|c|c|c|c|}
\hline Item & Teachers believe that: & $\begin{array}{l}\text { Strongly } \\
\text { Disagree }\end{array}$ & Disagree & $\begin{array}{l}\text { Neither } \\
\text { Agree nor } \\
\text { Disagree }\end{array}$ & Agree & $\begin{array}{l}\text { Strongly } \\
\text { Agree }\end{array}$ \\
\hline 2 & $\begin{array}{l}\text { The practice of code- } \\
\text { switching will increase } \\
\text { the learners' reliance } \\
\text { and dependency on the } \\
\text { teacher. }\end{array}$ & $\begin{array}{c}9.6 \% \\
(4)\end{array}$ & $\begin{array}{c}28.6 \% \\
(12)\end{array}$ & $\begin{array}{c}7.1 \% \\
(3)\end{array}$ & $\begin{array}{c}33.3 \% \\
(14)\end{array}$ & $\begin{array}{c}21.4 \% \\
(9)\end{array}$ \\
\hline 4 & $\begin{array}{l}\text { There should be a strict } \\
\text { separation of the } \\
\text { mother tongue and } \\
\text { English in the ESL } \\
\text { classroom. }\end{array}$ & $\begin{array}{c}2.3 \% \\
(1)\end{array}$ & $\begin{array}{c}38.1 \% \\
(16)\end{array}$ & $16.7 \%(7)$ & $\begin{array}{c}31.0 \% \\
(13)\end{array}$ & $\begin{array}{c}11.9 \% \\
(5)\end{array}$ \\
\hline 5 & $\begin{array}{l}\text { Code-switching should } \\
\text { only be used as a last } \\
\text { resort when all other } \\
\text { options have been } \\
\text { exhausted. }\end{array}$ & $\begin{array}{c}7.1 \% \\
(3)\end{array}$ & $\begin{array}{c}23.8 \% \\
(10)\end{array}$ & $14.3 \%(6)$ & $\begin{array}{c}26.2 \% \\
(11)\end{array}$ & $\begin{array}{c}28.6 \% \\
(12)\end{array}$ \\
\hline 6 & $\begin{array}{l}\text { Code-switching is an } \\
\text { efficient, time saving } \\
\text { technique. }\end{array}$ & $\begin{array}{c}2.4 \% \\
(1)\end{array}$ & $\begin{array}{c}35.7 \% \\
(15)\end{array}$ & $14.3 \%(6)$ & $\begin{array}{c}35.7 \% \\
(15)\end{array}$ & $\begin{array}{c}11.9 \% \\
(5)\end{array}$ \\
\hline 10 & $\begin{array}{l}\text { The more English that is } \\
\text { used, the better the } \\
\text { results for the learners. }\end{array}$ & $11.9 \%(5)$ & $\begin{array}{c}23.8 \% \\
(10)\end{array}$ & $\begin{array}{c}9.5 \% \\
(4)\end{array}$ & $\begin{array}{c}33.3 \% \\
(14)\end{array}$ & $\begin{array}{c}21.4 \% \\
(9)\end{array}$ \\
\hline
\end{tabular}

$54.7 \%$ of the teachers believe that code-switching could make learners rely and depend more on the teacher. Most of the teachers also agreed that code-switching should be used as a last choice when other options have been tried. Teachers also believed that using more English in the classroom yielded better results for the learners as the exposure time to English is increased. There is a balance between the percentage of teachers who think that code-switching is an important part of the ESL lessons. In the meantime, not all teachers think that code-switching is a technique that can help them save time as opposed to the studies conducted by Levine (2003); Sert (2005); Chowdhury (2013); DeAlwis (2020).

\section{Overall Perceptions}

Based on these findings, the teachers have mixed perceptions on the use of codeswitching. This portrayed the current position of code-switching in Malaysian ESL classrooms. Although the teachers know that code-switching is inevitable, they are trying their best not to practice it in their classroom. This might be due to the strict policy by the education officers who discouraged the use of L1 in ESL classrooms. However, as teachers are entrusted with their professional judgments, they believe that code-switching enables learning for low proficiency learners. 


\section{Teachers' Code-Switching Practice}

Table 5, 6 and 7 shows how teachers use code-switching in their ESL classrooms based on the three categories outlined by Ferguson (2003), code-switching to (i) understand the lesson content; (ii) manage discipline and classroom behaviour; and (iii) build relationship and engage learners.

\section{Code-switching to understand the lesson content}

Table 5: Teachers' Code-switching to understand the lesson content

\begin{tabular}{|l|c|c|c|c|c|}
\hline I use code-switching to: & $\begin{array}{c}\text { Never } \\
\text { (\%) }\end{array}$ & $\begin{array}{c}\text { Rarely } \\
\text { (\%) }\end{array}$ & $\begin{array}{c}\text { Sometimes } \\
\text { (\%) }\end{array}$ & $\begin{array}{c}\text { Most of the } \\
\text { time } \\
\text { (\%) }\end{array}$ & $\begin{array}{c}\text { Always } \\
\text { (\%) }\end{array}$ \\
\hline Explain the activity to my students & 7.1 & 23.8 & 26.2 & 31.0 & 11.9 \\
\hline $\begin{array}{l}\text { Give instruction for complicated } \\
\text { task }\end{array}$ & 7.1 & 19.1 & 16.7 & 33.3 & 23.8 \\
\hline Check students' understanding & 7.1 & 21.4 & 16.7 & 33.3 & 21.5 \\
\hline Explain new words & 4.8 & 33.3 & 9.5 & 26.2 & 26.2 \\
\hline Explain grammar rules & 7.1 & 28.6 & 21.4 & 23.8 & 19.1 \\
\hline $\begin{array}{l}\text { Reduce time in explaining difficult } \\
\text { words }\end{array}$ & 9.5 & 23.8 & 23.8 & 26.2 & 16.7 \\
\hline Facilitate low proficiency students & 11.9 & 11.9 & 14.3 & 40.5 & 21.4 \\
\hline
\end{tabular}

As illustrated in Table 5, more than $60 \%$ of the teachers chose 'sometimes' to 'always' for all the items with an average of $69.1 \%$. A higher percentage of teachers use code-switching to give instruction (73.8\%) and check students' understanding (71.5\%). A significant number of teachers (76.2\%) also chose 'sometimes' to 'always' about using code-switching to facilitate low proficiency learners. This finding is in accordance with DeAlwis (2020).

\section{Code-switching to manage discipline and classroom behaviour}

Table 6: Teachers' Code-switching to manage discipline and classroom behaviour

\begin{tabular}{|l|c|c|c|c|c|}
\hline I use code-switching to: & $\begin{array}{c}\text { Never } \\
(\%)\end{array}$ & $\begin{array}{c}\text { Rarely } \\
(\%)\end{array}$ & $\begin{array}{c}\text { Sometimes } \\
(\%)\end{array}$ & $\begin{array}{c}\text { Most of the } \\
\text { time } \\
(\%)\end{array}$ & $\begin{array}{c}\text { Always } \\
\text { (\%) }\end{array}$ \\
\hline Organize the classroom setting & 11.9 & 21.4 & 21.5 & 33.3 & 11.9 \\
\hline Save time in giving instructions & 9.5 & 28.6 & 19.1 & 28.6 & 14.2 \\
\hline $\begin{array}{l}\text { Get the students into desirable } \\
\text { groups }\end{array}$ & 9.5 & 28.6 & 16.7 & 33.3 & 11.9 \\
\hline $\begin{array}{l}\text { Maintain classroom rules among } \\
\text { students }\end{array}$ & 9.5 & 21.4 & 26.2 & 35.8 & 7.1 \\
\hline $\begin{array}{l}\text { Enhance students' engagement in } \\
\text { the activities }\end{array}$ & 4.8 & 21.4 & 21.4 & 40.5 & 11.9 \\
\hline Control students' discipline & 16.7 & 14.3 & 28.6 & 26.1 & 14.3 \\
\hline
\end{tabular}

Table 6 shows the functions of code switching to manage discipline and classroom behaviour. More than $60 \%$ of the teachers, with an average of $67.1 \%$, indicated that they 'sometimes', 'most of the time' and 'always' used these code-switching functions. A substantial number of teachers (73.8\%) use code-switching to enhance the learners' engagement in classroom activities. However, in the open-ended question, teachers barely mentioned any of this function mainly because they might not regard this as an important function in code-switching or it could be done subconsciously as a daily routine. 


\section{Code-switching to build relationship and engage learners}

Table 7: Teachers' Code-switching to build relationship and engage learners

\begin{tabular}{|l|c|c|c|c|c|}
\hline I use code-switching to: & $\begin{array}{c}\text { Never } \\
\text { (\%) }\end{array}$ & $\begin{array}{c}\text { Rarely } \\
\text { (\%) }\end{array}$ & $\begin{array}{c}\text { Sometimes } \\
\text { (\%) }\end{array}$ & $\begin{array}{c}\text { Most of } \\
\text { the time } \\
\text { (\%) }\end{array}$ & $\begin{array}{c}\text { Always } \\
\text { (\%) }\end{array}$ \\
\hline Praise my students & 11.9 & 38.1 & 14.3 & 21.4 & 14.3 \\
\hline Attract students' attention & 11.9 & 21.4 & 16.7 & 38.1 & 11.9 \\
\hline Build good rapport with my students & 9.5 & 28.6 & 11.9 & 35.7 & 14.3 \\
\hline Decrease students' level of anxiety & 9.5 & 19.0 & 16.7 & 38.1 & 16.7 \\
\hline $\begin{array}{l}\text { Provide opportunity for students to } \\
\text { communicate naturally }\end{array}$ & 4.8 & 19.0 & 26.2 & 31.0 & 19.0 \\
\hline
\end{tabular}

As mentioned by DeAlwis (2020); Flyman-Mattsson \& Burenhult (1999); Sert (2005), code-switching also serves as an emotional function where teachers use them to build a better interpersonal relationship with the learners. Table 7 demonstrated that more than $60 \%$ of teachers (average 65.3\%) admitted using code-switch to attract learners' attention, to build good rapport, and to decrease learners' anxiety. Many teachers also use code-switching to provide opportunities for learners to communicate naturally. However, only $50 \%$ of the teachers use code-switching to praise their students which is the lowest percentage.

When comparing the three categories of code-switching functions, it is quite clear that more teachers utilized code-switching to help learners understand lesson content than to manage discipline or to build relationships with the learners.

\section{Open-ended question}

The open-ended questions are important to obtain teachers' perceptions and use of code-switching in their own exact words. Their answers were analyzed thematically based on previous studies by Makulloluwa (2013), Chen \& Maarof (2017), Tajgozari (2017) and DeAlwis (2020). Table 8 shows original answers from the teachers regarding their perceptions and use of code-switching in their ESL classrooms. 
Table 8: Open-ended question's responses

It's not wrong to be used, besides it is essential for ESL learners.

Students are found to be more interactive and willing to engage in classroom activities.

I use code switching occasionally in class to make sure the objectives of my lesson are achieved. However, I make sure I do not use too much of it.

I think code-switching can facilitate weaker students because students understand better if it is translated.

I would rather use CS in my practice as it represents the class. I must respect the fact that they learn their mother tongue first and not English. Using it side by side IMO would facilitate students' learning process and may open their eyes to the big possibility of understanding English through their mother tongue.

It helps to reduce my pupils' anxiety level when learning a language that is so foreign to them.

ESL teachers should reduce the use of code switching in classroom to motivate pupils in using the target language

Useful for weak learners as it helps to reduce their anxiety in participating in the lessons

I use code-switching sometimes in my classroom for weaker students.

only apply code-switching in weak proficiency classes.

Very helpful for ESL learners to learn the language

Code-switching is helpful especially for low proficiency students. When I code-switch, students will understand the use of English words better as they can relate it to their mother tongue language

It helps me to explain English vocabulary better and it is good for weaker pupils.

We tried our best to keep using English during the teaching part and activity instruction. However, I realized it was too overwhelming for my pupils. So when they come to me for guidance, I will use both English and BM to enhance their understanding of their task.

Apply it to the less proficient kids

I try to avoid code-switching and use it as the last resort

Code-switching is a part of the English language classroom in Malaysia as we are a multilingual nation and English is taught as a second or sometimes unofficial third language. However, code-switching should be used as a last resort and teachers should be allowed to use code-switching in the classroom at a minimal level.

Students more responsive during lesson

It enables pupils to learn English language better.

Helpful in facilitating weaker learners

Only apply it when there is really a need.

Need to apply when you're teaching in low proficiency class

Can use code-switching but it should be minimum

Code switching is really needed sometimes, but we should not overuse it.

It is effective in language learning

Able to get weak learners attention when they struggle sometimes. And that is the best way to use code-switching.

I will only use code switching sometimes, but most of the time, I try to encourage students to speak only English language.

It's unavoidable! We could go on and on in English but if no one understands, what's the point, right? 


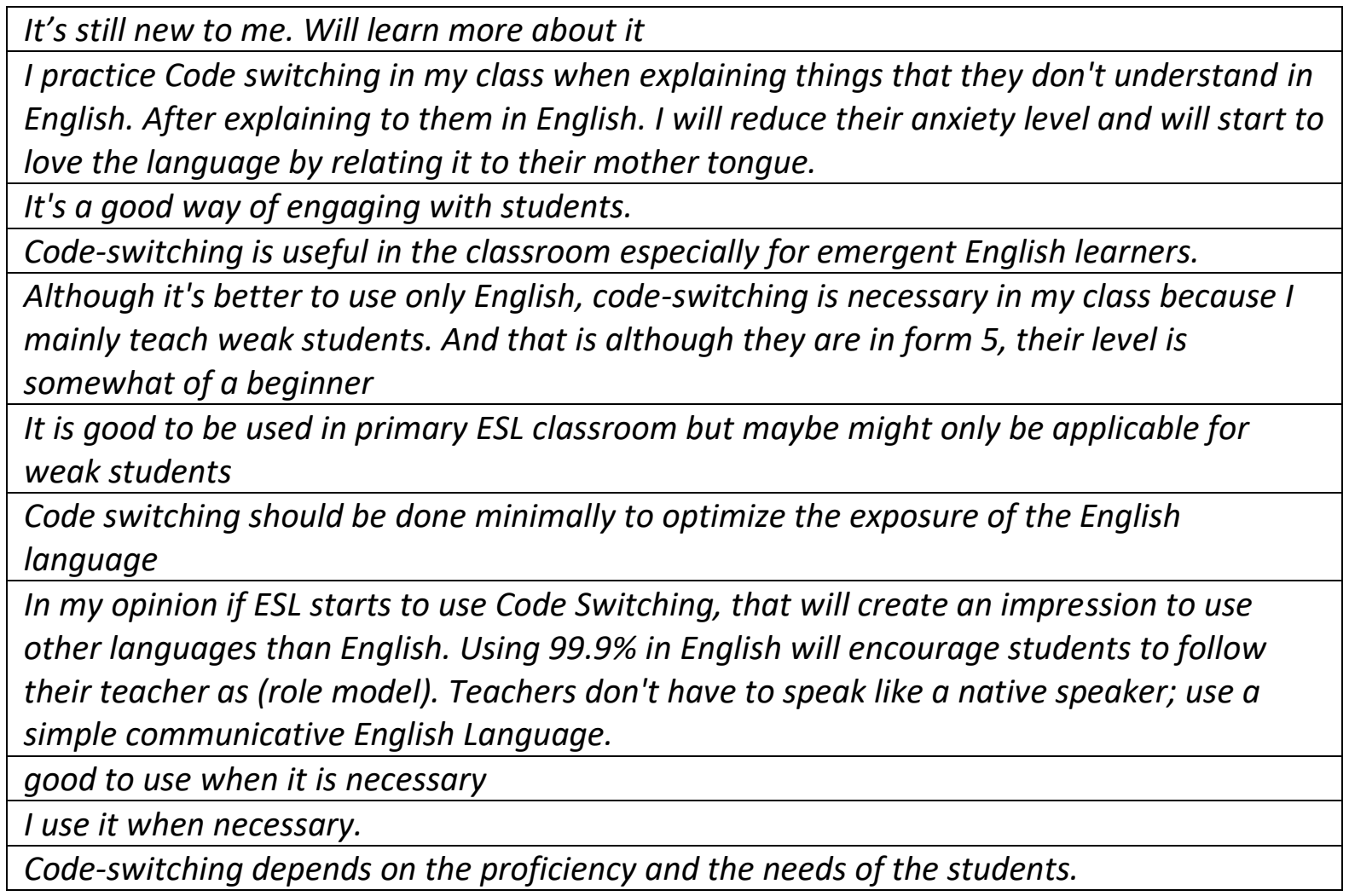

13 teachers showed generally positive perceptions towards code-switching where they reported the advantages of code-switching such as reducing the learners' anxiety, making them more willing to engage in classroom activities and becoming more responsive during ESL lessons. 13 teachers stated that code-switching is more useful for low proficiency learners which is in accordance with (DeAlwis, 2020; Makulloluwa, 2013). 7 teachers advocated for minimal use of code-switching because they were concerned about overusing code-switching that resulted in too much reliance on the learners' first language. This finding is aligned with the study conducted by Chen \& Maarof (2017) where they indicated that teachers should minimize the use of code-switching and practice it when necessary, according to certain pedagogical situations and reasons. 5 teachers pointed out that code-switching should be used as the last resort meanwhile 3 teachers do not support the use of codeswitching because it can decrease the learners' exposure time to English language hence, they encouraged their learners to speak English in the classroom as also supported by Tajgozari's (2017) study. All in all, the teachers showed mixed perception towards the use of codeswitching in ESL classrooms although it is unavoidable, useful, and effective. It is also important to note that 3 teachers mentioned that code-switching practice is still new to them probably because they were not exposed to it during their teachers' training days.

\section{Conclusion}

This study investigated the teachers' perceptions on code-switching practice in ESL classrooms and how they use it. The results suggested that the teachers have mixed perceptions on the use of code-switching. Furthermore, they advocated for judicious use of code-switching besides using it to help low proficiency learners. This perception further influences their use of code-switching where it was revealed that the teachers use codeswitching mostly to help learners understand lesson content. Although this study successfully portrayed the teachers' perceptions and use of code-switching in ESL classrooms, it did not explain in detail whether there is any relationship between the teachers' teaching experience 
with the amount of code-switching they use in ESL classrooms. Future research should focus on determining the correlation between teaching experience and the use of code-switching.

\section{References}

Ahmad, B. H., \& Jusoff, K. (2009). Teachers' Code-Switching in Classroom Instructions for Low English Proficient Learners. English Language Teaching, 2(2). https://doi.org/10.5539/elt.v2n2p49

Benu, N. N. (2018). Code Switching in EFL Classroom (A Case Study at a State Senior High School in Kupang). Exposure Journal, 7(2), 150-160.

Cheng, K. (2003). Code-switching for a purpose: Focus on pre-school Malaysian children. Multilingua, 22(1), 59-77.

Chowdhury, N. (2013). Classroom Code Switching of English Language Teachers at Tertiary Level: A Bangladeshi Perspective. Stamford Journal of English, 7, 40-61. https://doi.org/10.3329/sje.v7i0.14462

DeAlwis, C. (2020). Code-switching in Malaysian Classroom as the Microcosm of Society in Socio-cultural Context. International Journal of Service Management and Sustainability, 4(2), 135. https://doi.org/10.24191/ijsms.v4i2.8069

Haliza, E. I., Shah, A. M. I., \& Armia, N. T. (2013). Code-switching in english as a foreign language classroom: Teachers' attitudes. English Language Teaching, 6(7), 139-150. https://doi.org/10.5539/elt.v6n7p139

Ferguson, G. (2003). Classroom code-switching in post-colonial contexts. AlLA Review, 16(April), 38-51. https://doi.org/10.1075/aila.16.05fer

Flyman-Mattsson, A., \& Burenhult, N. (1999). Code-switching in second language teaching of \{French\}. Working Papers in Linguistics, 47(0), 59-72.

http://journals.lub.lu.se/index.php/LWPL/article/view/2322

Gumperz, J. J. (1982). The Communicative Competence of Bilinguals: Some Hypotheses and Suggestions for Research. Lang. Soc, 1, 143-154.

Iber, G. (2016). English Language Learning in the Malaysian School Setting: Where Can We Find 10,000 Hours? A Theoretical Perspective. Advances in Language and Literary Studies, 7(4). https://doi.org/10.7575/aiac.alls.v.7n.4p.46

Lee, H. (2010). Code switching in the teaching of English as a second language to secondary school students. Malaysian Journal of ELT Research, 6(December), 1-45.

Levine, G. S. (2003). Student and Instructor Beliefs and Attitudes about Target Language Use, First Language Use, and Anxiety: Report of a Questionnaire Study. The Modern Language Journal, 87(3), 343-364. https://doi.org/10.1111/1540-4781.00194

Makulloluwa, E. (2013). Code switching by teachers in the second language classroom. International Journal of Arts \& Sciences, 6(3), 581-598. http://universitypublications.net/ijas/0603/pdf/T3N299.pdf

Manara, C. (2007). Opinions and Practices in an Indonesian Context. Spring, 4(1), 145-178.

Milroy, L., \& Muysken, P. (1995). One speaker, two languages: Cross-disciplinary perspectives on code-switching. Cambridge: Cambridge University Press.

Khusmah, M., \& Su-Hie, T. (2016). Malaysian Youth's Receptivity Towards Code-Switching in Malay Drama Television Series. ESTEEM Academic Journal, 12(2), 31-46.

Paramesvaran, M. D., \& Lim, J. W. (2018). Code-switching practices in a Malaysian multilingual primary classroom from teacher and student perspectives. Indonesian Journal of Applied Linguistics, 8(2), 254-264. https://doi.org/10.17509/ijal.v8i2.13273 
Selamat, J. T. (2014). Code switching in the Malaysian ESL classroom. Master of Arts (Linguistic) Thesis, University of Otago.

Sert, O. (2005). The Functions of Code-Switching in ELT Classrooms. The Internet TESL Journal, 11(8), 7. https://doi.org/10.24191/smrj.v16i2.7068

Tajgozari, M. (2017). Factors Contributing to the Use of L1 in English Classrooms: Listening to the Voice of Teachers and Students in Iranian Institutes. International Journal of Research in English Education, 2(2), 63-75. https://doi.org/10.18869/acadpub.ijree.2.2.63

Wardhaugh, R., \& Fuller, J. M. (2014). An introduction to sociolinguistics. John Wiley \& Sons. Zohrabi, M. (2013). Mixed method research: Instruments, validity, reliability and reporting findings. Theory and Practice in Language Studies, 3(2), 254-262.

https://doi.org/10.4304/tpls.3.2.254-262 